\title{
Modelling Real-Time Pricing of Electricity for Energy Conservation Measures in the UK Commercial Sector
}

\author{
Salvador Acha \\ IEEE Member \\ Centre for Process Systems Engineering \\ Department of Chemical Engineering \\ Imperial College London \\ London, UK \\ salvador.acha@ic.ac.uk
}

\author{
Gonzalo Bustos-Turu \\ IEEE Member \\ Centre for Process Systems Engineering \\ Department of Chemical Engineering \\ Imperial College London \\ London, UK \\ gb1612@imperial.ac.uk
}

\author{
Nilay Shah \\ Centre for Process Systems Engineering \\ Department of Chemical Engineering \\ Imperial College London \\ London, UK \\ n.shah@imperial.ac.uk
}

\begin{abstract}
Electricity bills in the UK are increasing year after year due to power market conditions and they will most likely continue to rise. These high costs are reducing the profitability of businesses and thus efforts on understanding and mitigating these charges are a key concern for companies in order to improve their bottom line. This paper focuses on detailing a comprehensive bottom-up model of electricity commercial bills that generates real-time price curves; thus allowing customers to comprehend the true cost of electricity over time for different UK regions across various seasons. Such insights provide clarity and are valuable because they can be used to inform efficiency programs; thus allowing decision makers to evaluate more accurately the return on investment their initiatives can have. Results overall show Yorkshire has the highest rates, while the South West has the most expensive peaks. Meanwhile, London and Southern England have the cheapest rates.
\end{abstract}

Index Terms - energy markets, modelling electricity tariffs, network charges, real-time pricing

\section{INTRODUCTION}

Electricity bills in the UK are among the most expensive in Europe for non-domestic consumers [1]. Although after the liberalization of the power sector in the 1990's costs dropped, this trend has radically changed in the past decade. The average commercial customer rates from 2004 to 2015 rose by $264 \%$ (from $4.02 \mathrm{p} / \mathrm{kWh}$ to $10.62 \mathrm{p} / \mathrm{kWh}$ ) [2]. The needs to invest in both new conventional and renewable power plants as well as in transmission and distribution infrastructure are the main reasons behind surging electricity costs [3]. Due to the existing power system challenges, costs will continue to rise in the foreseeable future [4]. These high costs are reducing the profitability of energy intensive businesses and hence efforts on understanding and mitigating these charges are a key priority for UK companies if they wish to remain competitive. As a consequence, businesses are becoming more conscious and proactive in terms of energy management [5]. However, due to the complex billing structure and diverse procurement strategies an accurate representation of the true cost of electricity in real-time is difficult to portray [6]. This fact has the perverse effect of distorting energy efficiency programs as consumers do not fully understand at what time of the day and in which periods of the year they are paying the most or the least for electricity consumption.

Based on this energy context, UK businesses that are energy savvy need taking decisive actions to:

- Keep updated on energy markets and policy;

- Learn in detail how energy is used;

- Comprehend electricity billing structure;

- Identify best times to reduce energy use;

- Understand most suitable technologies to reduce demand;

- Make investments enhancing bottom line while reducing market exposure

Based on context explained, there is a necessity to develop decision support tools for proactive consumers to improve the way they use energy. Accordingly, this paper focuses on detailing a bottom-up model of electricity commercial bills that generates real-time price curves; thus allowing customers to comprehend the true cost of electricity over time for different UK regions across various seasons. Such modelling insights provide clarity to decision makers as it allows them to evaluate more accurately the return on investment their energy efficiency initiatives can achieve. Therefore, it may help trigger initiatives ranging from demand side management up to on-site generation investments. The paper has the following structure: a) the current UK electricity bill for commercial customers is defined and explained, b) key stakeholders and data sources are outlined, c) the modelling approach is described, c) real-time cost profiles are illustrated for different day types and across different UK regions, d) the paper concludes by highlighting the knowledge contribution of this work as well as discussion of key results while also outlining next steps of further work in this exciting research field. 


\section{UK ELECTRICITY BILL BREAKDOWN}

Table I details each tariff component found in UK commercial electricity bills for the financial year 2015-16. Figure 1 shows the role each component has on total cost.

TABLE I. UK TARIFF COMPONENTS

\begin{tabular}{|c|c|}
\hline Element & Description \\
\hline Energy & $\begin{array}{l}\text { Cost of the electricity purchased on the wholesale market } \\
\text { usually set via bilateral contracts and representing about } \\
48 \% \text { of total energy cost [7]. }\end{array}$ \\
\hline DuoS & $\begin{array}{l}\text { Use charges covering the costs of operating distribution } \\
\text { systems; at about } 15 \% \text { of the bill they are reviewed annually. } \\
\text { Charges vary within the } 14 \text { distribution network operators } \\
\text { (DNOs) based on voltage connection and time of use [8]. }\end{array}$ \\
\hline TNuoS & $\begin{array}{l}\text { Use charges covering the costs of operating transmission } \\
\text { networks represent around } 5 \% \text { of the bill and fees are revised } \\
\text { annually. The charge varies across } 14 \text { zones and is set based } \\
\text { on user's average half-hourly demand over three Triad } \\
\text { periods taking place every winter season [9]. }\end{array}$ \\
\hline Dloss & $\begin{array}{l}\text { Distribution losses are set through Line Loss Factors (LLFs) } \\
\text { by DNOs and are time and season dependent; they represent } \\
\text { about } 3 \% \text { of the bill [8]. }\end{array}$ \\
\hline Tloss & $\begin{array}{l}\text { Transmission loss multipliers (TLMs) are used to set charges } \\
\text { for transmission losses, which are calculated every half-hour } \\
\text { (1\% of the bill) [9]. }\end{array}$ \\
\hline BSUoS & $\begin{array}{l}\text { Balancing charge that recovers the cost of day to day } \\
\text { operation of the transmission system through half-hourly } \\
\text { settlements ( } 3 \% \text { of the bill) [10]. }\end{array}$ \\
\hline$R O$ & $\begin{array}{l}\text { The renewables obligation addresses the cost of supporting } \\
\text { renewable projects. This scheme forces suppliers to purchase } \\
\text { varying renewable energy quotas each year and has no } \\
\text { temporal or spatial dependency ( } 14 \% \text { of the bill) [11]. }\end{array}$ \\
\hline FiT & $\begin{array}{l}\text { Complementing ROs, the Feed-in-Tariff scheme is a } \\
\text { program from the government to promote the use of small- } \\
\text { scale low-carbon generation technologies (less than 5MW); } \\
\text { making } 4 \% \text { of the bill [12]. }\end{array}$ \\
\hline$C C L$ & $\begin{array}{l}\text { The climate change levy is a tax on business energy use. The } \\
\text { final recipient of supplies of electricity generated from } \\
\text { certain renewable sources and combined heat and power } \\
\text { enjoy exemptions ( } 6 \% \text { of the bill) [13]. }\end{array}$ \\
\hline Others & $\begin{array}{l}\text { Procurement management fees and assistance for areas with } \\
\text { high electricity distribution costs (AAHEDC) are negligible } \\
\text { [14]. Meanwhile, recent market reform initiatives contracts } \\
\text { for difference (CfD) and the capacity mechanism (CapM) } \\
\text { still have no palpable impact on consumers }[15,16] .\end{array}$ \\
\hline
\end{tabular}

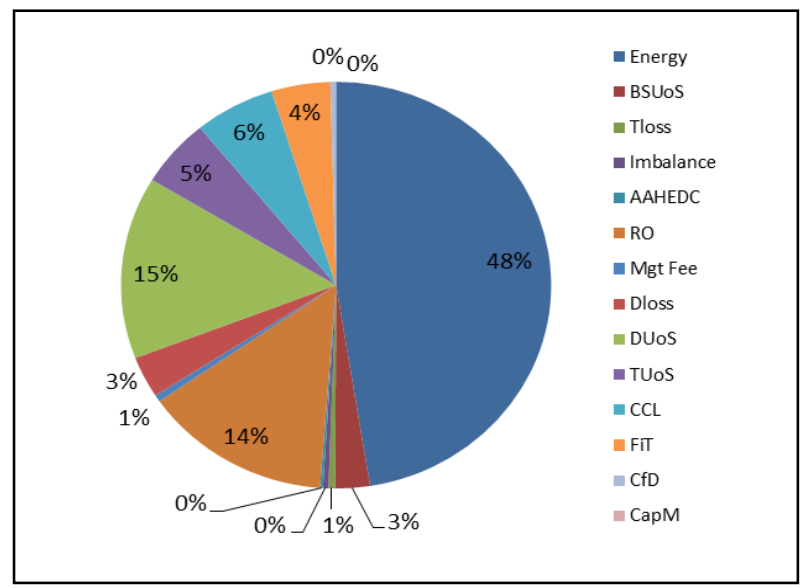

Figure 1. 2015 electricity bill breakdown for commercial UK consumers.

\section{UK POWER MARKET FEATURES}

Once the tariff components that determine the cost of electricity have been comprehended, it is necessary to understand the intrinsic features of the cost data available and how frequent these are updated. By identifying the dynamics each billing component has it makes possible to envisage the influence they have in shaping the cost profiles of consumers. Therefore, when such interactions are accounted for and aggregated it is possible quantify the cost of electricity in realtime; providing rich temporal and spatial information.

\section{A. Data Sources and Review Periods}

Table II outlines the data sources in setting tariffs and how often these are reviewed.

TABLE II. UK POWER MARKet COSTING FeAtURES

\begin{tabular}{|c|c|c|}
\hline Element & Data Sources \& Features & Review Period \\
\hline Energy & $\begin{array}{l}\text { Half-hourly settlement periods based } \\
\text { on market index price (MIP) available } \\
\text { at the Elexon portal [7]. }\end{array}$ & $\begin{array}{l}\text { Long term } \\
\text { contracts are norm, } \\
\text { but trading can be } \\
\text { done up to } 1 \text { hour } \\
\text { before gate closes }\end{array}$ \\
\hline Duos & $\begin{array}{l}\text { Three time band rates on weekdays } \\
\text { (red, amber, green), while green band } \\
\text { applies on weekends. Fixed and } \\
\text { variable costs vary on rate and voltage } \\
\text { connection. Reactive power is charged } \\
\text { too. Info is published separately by } \\
\text { each DNO [8]. }\end{array}$ & $\begin{array}{l}\text { Fixed annually - } \\
\text { updated February } \\
\text { and effective from } \\
1^{\text {st }} \text { April }\end{array}$ \\
\hline TNuoS & $\begin{array}{l}\text { Based on Triad days (system peaks) } \\
\text { measured each year between } 16 \text { to } 19 \\
\text { hours November to February. Data } \\
\text { released by National Grid; the system } \\
\text { operator [9]. }\end{array}$ & $\begin{array}{l}\text { Tariffs published } \\
\text { by } 31^{\text {st }} \text { January } \\
\text { and take effect } \\
\text { from } 1^{\text {st }} \text { April }\end{array}$ \\
\hline Dloss & $\begin{array}{l}\text { DNOs calculate the LLFs and provide } \\
\text { these factors to Elexon. Info is } \\
\text { published separately by each DNO } \\
\text { [8]. }\end{array}$ & $\begin{array}{l}\text { Fixed annually - } \\
\text { updated February } \\
\text { and effective from } \\
1^{\text {st }} \text { April }\end{array}$ \\
\hline Tloss & $\begin{array}{l}\text { ELEXON, through the Balancing and } \\
\text { Settlement Code (BSC) sets out the } \\
\text { rules for how transmission network } \\
\text { users pay for losses [9]. }\end{array}$ & $\begin{array}{l}\text { Calculated for } \\
\text { each settlement } \\
\text { period (half hour) }\end{array}$ \\
\hline BSUoS & $\begin{array}{l}\text { National grid provides a monthly } \\
\text { forecast of BSuoS; generators and } \\
\text { suppliers are liable for these charges } \\
\text { and has no spatial variability [10]. }\end{array}$ & $\begin{array}{l}\text { Half hour } \\
\text { settlement periods }\end{array}$ \\
\hline $\begin{array}{l}\text { RO, FiT, } \\
C C L, C f D \\
C M\end{array}$ & $\begin{array}{l}\text { Tariff set by government and enforced } \\
\text { by Ofgem; it has no temporal or } \\
\text { spatial dependency }[11,12,13] \text {. }\end{array}$ & $\begin{array}{l}\text { Fixed annually - } \\
\text { taking effect on } 1^{\text {st }} \\
\text { April }\end{array}$ \\
\hline
\end{tabular}

\section{B. Regional Pricing}

As explained in the previous sections, within the UK there are differences in costs per $\mathrm{kWh}$ delivered between geographical locations due to varying DuoS and TNuoS charges. This is due to the fact that delivering power to different parts of the country is costed based on efficiency; which is influenced by topology and asset management. There are 14 DNOs, spread across 6 companies, and similarly there are 14 transmission demand tariffs [17]. Accounting and identifying these areas is highly relevant to develop an accurate representation of real-time costs of electricity. Figure 2 and Table III showcase the DNO regions in the UK. 


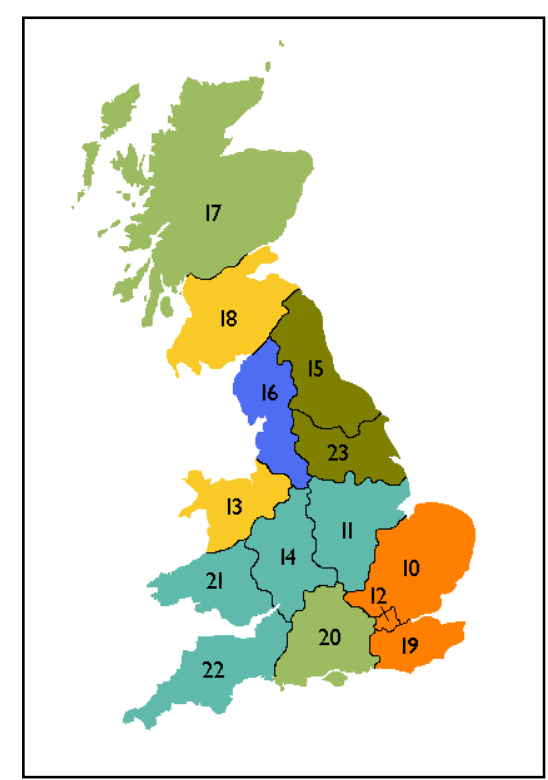

Figure 2. UK Electricity distribution map [18].

Note: Northern Ireland has been omitted from this study as its costing mechanisms are not similar to the ones in mainland Britain [19].

TABLE III. UK ELECTRICITY DISTRIBUTION MAP

\begin{tabular}{|l|l|}
\hline \multicolumn{1}{|c|}{ Numbers } & \multicolumn{1}{c|}{ Operator Details } \\
\hline $10,12,19$ & UK Power Networks (UKPN) [20] \\
\hline $11,14,21,22$ & Western Power Distribution (WPD) [21] \\
\hline 15,23 & Northern Power Grid (NPG) [22] \\
\hline 13,18 & SP Energy Networks (SPEN) [23] \\
\hline 16 & Electricity North West (ENW) [24] \\
\hline 17,20 & Scottish and Southern Energy (SSE) [25] \\
\hline
\end{tabular}

\section{Modelling Methodology \& SCOPE OF AnAlysis}

This section focuses on explaining the approach employed to develop UK real-time cost profiles of electricity. Particular emphasis is put on the considerations taken in order to model half-hourly prices of electricity for 4 typical days of the year. Hence, the spatial and temporal features of the various tariff elements need to be comprehended.

\section{A. Seasonal Scenarios}

Since TNuoS are charged based on the Triad consumption metered between November to February it was decided to "cost" this element in this particular time period. Therefore, in this work we make a distinction between days from March to October and those from November to February. More specifically, since Triads are bound to occur between 4 to 7 p.m. the allocated TNuoS charges in this model were applied within this time frame; particularly between 5 and $6.30 \mathrm{p} . \mathrm{m}$. as the historical data shows this is the time most likely Triad measurements are to occur [26].

\section{B. Day Type Scenarios}

Two day types are simulated in this work: weekdays (WD) and weekends (WE). This consideration arise because the wholesale market prices are quite distinctive from Monday to Friday when compared to Saturday and Sunday; primarily because on weekends only base block clips can be purchased [27]. In addition, red, amber, and green DuoS charges only apply during weekdays, while in the weekend only green charges apply. Such dynamics justify distinguishing separately cost profiles of weekdays and weekends.

\section{Spatially Fixed Tariffs}

This section outlines how tariff data which is fixed for the whole of UK (albeit some these may be time dependent) was processed for modelling purposes.

- Energy: varies half-hourly, most expensive in winter (i.e. high demand) and least expensive in summer (i.e low demand). 2014 representative average data was calculated for 4 typical days from data collected in the Elexon portal [7].

- BSUoS: varies half-hourly and is most expensive in winter. 2014 representative average data was obtained from National Grid [10].

- Tloss: varies half-hourly and spatially using TLMs and transmission loss factors (TLFs). Data was obtained from the Elexon portal [9].

- RO/FiT/CCL/CfD/CM: since tariffs are set in advance they have been evenly distributed across each half-hourly interval, except for the Capacity Mechanism which is applied at the same period as TNuoS charges $[11,12,13,14,15,16]$.

\section{Spatially Variable Tariffs}

This section outlines how tariff data which varies across DNO regions in the UK (and usually is time dependent too) was processed for modelling purposes.

- DuoS: charges are composed of 3 key groups fixed, variable, and reactive power [8]. Fixed fee is set by DNO based on local capacity and voltage connection daily rates, this cost was distributed evenly across each half-hourly intervals. Variable rates come from DNO charging statements specifying time bands. These were applied for each region assuming a low voltage substation $\mathrm{HH}$ metered connection (i.e. commercial user). Reactive charges are applied across each half-hourly intervals based on $\mathrm{kVARh}$ measured at 0.98 power factor.

- Dloss: DNOs set LLFs for a region into different periods (similar to red, amber, green bands). These were applied for each region assuming a low voltage substation $\mathrm{HH}$ metered connection (i.e. commercial user) [8].

- TNuoS: National Grid's HH Demand Tariffs were revised to set a rate for DNO regions and applied in weekdays from November to February [9]. 


\section{E. Methodology}

The total cost of electricity in $\mathfrak{f} / \mathrm{kWh}$ for each half-hourly interval in a particular DNO region is calculated using the following expression:

$$
\text { Cost }_{(s, d, t)}=\text { Fixed } \operatorname{Tariff}_{(s, d, t)}+\text { Variable Tariffs }_{(s, d, t)}
$$

The cost of electricity is hence a function of the season $(s)$, day type $(d)$ and interval in time $(t)$ being assessed. The fixed tariffs are the ones described in Section IV-C while the variable tariffs are the ones outlined in Section IV-D.

\section{ReAl-Time Electricity Cost Profiles}

The modelling approach described in the previous section was used to simulate the 14 UK DNO regions. From the simulations 56 electricity profiles for 2015-16 were produced.

\section{A. Day Types}

The capacity to simulate prices in half-hourly intervals offers very relevant insights into how the cost of electricity varies across different day types. Figures 3 to 6 illustrate the 56 electricity profiles generated; meanwhile Table IV details statistical results of each day type. Results clearly show weekdays have the highest level of fluctuation with distinctive peaks in the early evening, while weekend profiles are a bit more flat in nature. From the figures it is evident that November to February is the more expensive period.

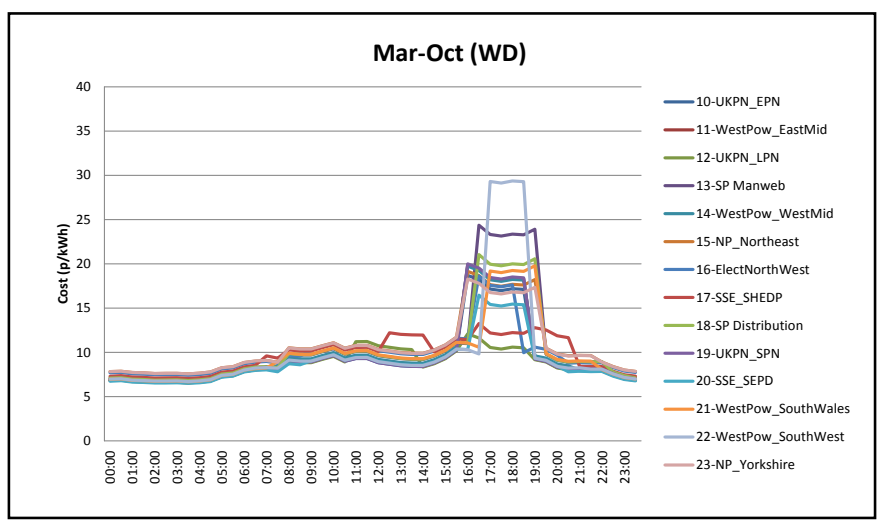

Figure 3. March to October weekday electricity cost profiles.

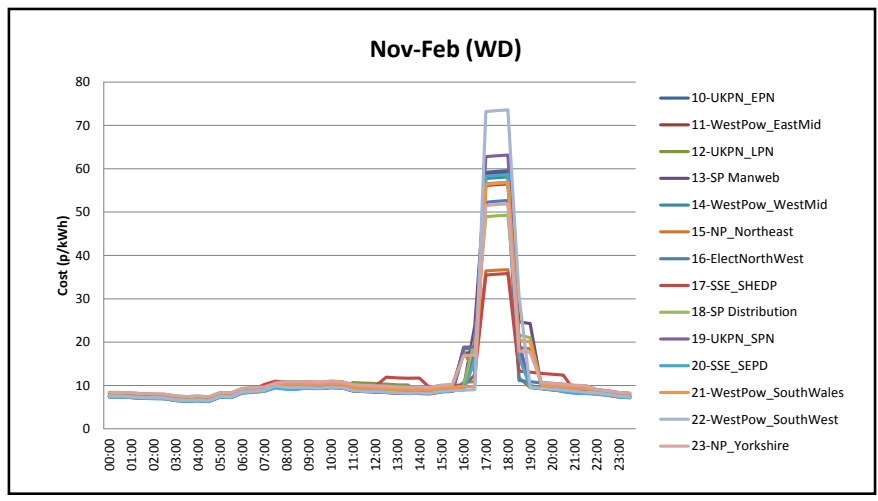

Figure 4. November to February weekday electricity cost profiles.

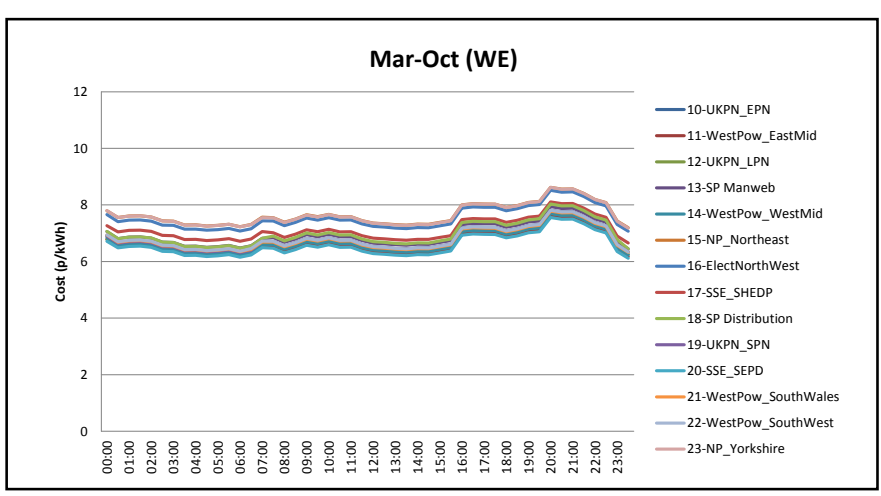

Figure 5. March to October weekend electricity cost profiles.

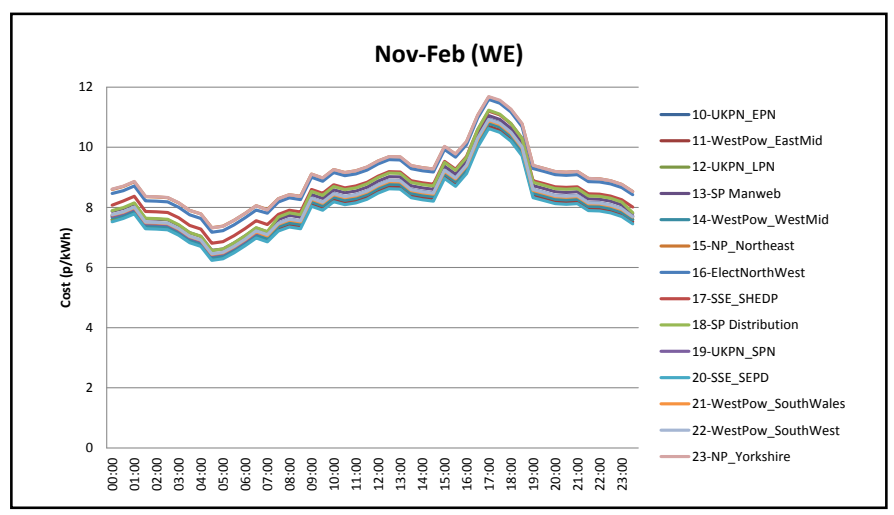

Figure 6. November to February weekend electricity cost profiles

TABLE IV. Base, Average, ANd Peak Costs (P/KWH)

\begin{tabular}{|l|c|c|c|c|}
\hline \multicolumn{1}{|c|}{ Period } & Minimum & Average & Peak & $\begin{array}{c}\text { Peak to } \\
\text { Base Ratio }\end{array}$ \\
\hline $\begin{array}{l}\text { March- } \\
\text { October WD }\end{array}$ & 6.50 & 9.73 & 29.36 & 4.52 \\
\hline $\begin{array}{l}\text { November- } \\
\text { February WD }\end{array}$ & 6.26 & 12.11 & 73.56 & 11.75 \\
\hline $\begin{array}{l}\text { March- } \\
\text { October WE }\end{array}$ & 6.11 & 6.98 & 8.62 & 1.41 \\
\hline $\begin{array}{l}\text { November- } \\
\text { February WE }\end{array}$ & 6.24 & 8.40 & 11.69 & 1.87 \\
\hline
\end{tabular}

The results allow us to reach the following understanding:

- Average annual electricity cost is $9.63 \mathrm{p} / \mathrm{kWh}$.

- Minimum electricity costs do not vary substantially; averaging $6.28 \mathrm{p} / \mathrm{kWh}$ and occur mostly in the early hours of weekdays as well as some hours in the weekend.

- Average prices vary considerably between day types and seasons. March - October weekdays are 39\% more expensive than weekends, while November - February weekdays are $44 \%$ more expensive than weekends.

- Peak charges during March - October weekdays are 3 times the average cost, while for NovemberFebruary weekdays this value is 6 . 


\section{B. Regional Rankings}

This section goes in more depth in analyzing the subtleties between UK regions in terms of average cost and peak costs. By combining the datasets presented in the previous section a normalized annual weighted average was calculated as the March to October cost profiles are more frequent (245 days) than the November to February period (120 days). Figure 7 illustrates the UK DNO map in which the red circles indicate most expensive areas and the green circles indicate lower cost areas, meanwhile Table $\mathrm{V}$ ranks each region by average cost from most expensive to least expensive.

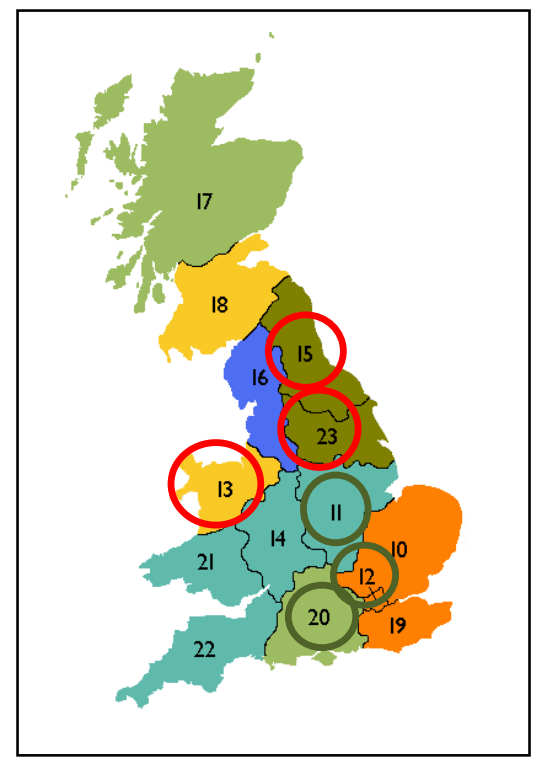

Figure 7. Most (red) and least (green) expensive regions in the UK.

TABLE V. 2015-16 AVERAGE UK ELECTRICITY COSTS

\begin{tabular}{|c|c|c|}
\hline Region & DNO & Cost (p/kWh) \\
\hline 23 & NPG Yorkshire & 10.29 \\
\hline 13 & SPEN Merseyside \& Northern Wales & 10.16 \\
\hline 15 & NPG North Eastern England & 10.13 \\
\hline 22 & WPD South Western England & 9.90 \\
\hline 16 & ENW North Western England & 9.87 \\
\hline 18 & SPEN Southern Scotland & 9.81 \\
\hline 21 & WPD Southern Wales & 9.62 \\
\hline 19 & UKPN South Eastern England & 9.51 \\
\hline 17 & SSE Northern Scotland & 9.49 \\
\hline 14 & WPD West Midlands & 9.47 \\
\hline 10 & UKPN Eastern England & 9.36 \\
\hline 11 & WPD East Midlands & 9.33 \\
\hline 20 & SSE Southern England & 8.99 \\
\hline 12 & UKPN London & 8.92 \\
\hline
\end{tabular}

Table VI ranks each region by most expensive peaks for the periods of November to February and March to October.

TABLE VI. 2015-16 PEAK UK ELECTRICITY COSTS

\begin{tabular}{|c|c|c|c|c|}
\hline Region & $\begin{array}{c}\text { Nov-Feb } \\
(\mathbf{p} / \mathbf{k W h})\end{array}$ & $\begin{array}{c}\text { Nov-Feb } \\
\text { Ranking }\end{array}$ & $\begin{array}{c}\text { Mar-Oct } \\
(\mathbf{p} / \mathbf{k W h})\end{array}$ & $\begin{array}{c}\text { Mar-Oct } \\
\text { Ranking }\end{array}$ \\
\hline 10 & 59.56 & 3 & 18.70 & 9 \\
\hline 11 & 56.62 & 9 & 19.89 & 5 \\
\hline 12 & 56.87 & 7 & 12.09 & 14 \\
\hline 13 & 59.15 & 4 & 24.37 & 2 \\
\hline 14 & 58.13 & 6 & 19.73 & 7 \\
\hline 15 & 36.72 & 13 & 19.15 & 8 \\
\hline 16 & 52.64 & 10 & 18.63 & 10 \\
\hline 17 & 35.84 & 14 & 13.26 & 13 \\
\hline 18 & 49.32 & 12 & 21.05 & 3 \\
\hline 19 & 63.18 & 2 & 20.00 & 4 \\
\hline 20 & 58.63 & 5 & 16.46 & 12 \\
\hline 21 & 56.77 & 8 & 19.79 & 6 \\
\hline 22 & 73.56 & 1 & 29.36 & 1 \\
\hline 23 & 51.89 & 11 & 18.29 & 11 \\
\hline
\end{tabular}

As Tables V and VI show, it is abundantly clear that regions with the highest peaks of electricity are not a precursor for high annual costs. This means other factors such as DNO fixed and variable tariffs (e.g. green and amber rates) as well as Dloss and reactive power have a relevant weight when compounded across a year to shift the costs the ranking. For example, the region NPG Yorkshire has the most expensive rate over a year in the UK, but its peak values of electricity are ranked $11^{\text {th }}$ for both seasonal periods assessed in this study. Meanwhile, WPD South Western England has the most expensive peaks but ranks $4^{\text {th }}$ when average cost is calculated.

\section{CONCLUSION}

UK electricity prices have risen substantially in the last few years and they are projected to continue to rise. These spiraling high costs are reducing the profitability of businesses and hence efforts on understanding and mitigating these charges are a key priority for UK companies so they can improve their profit margins. This paper has focused on detailing a bottom-up model of electricity commercial bills generating real-time price curves; thus allowing customers to comprehend the true cost of electricity over time for different UK regions so more effective energy efficiency programs can be devised. Results have shown the valuable insights customers can achieve in identifying at what moments in time they pay the most for electricity. Hence, companies should employ this type of information to devise more innovative and accurate business cases that provide more certainty in the rate of return that can be achieved. 
The methodology presented in this work has focused in explaining all the tariff elements and how when these are combined real-time cost electricity profiles can be generated. In this paper results focused on showcasing and comparing 4 typical days of the 2015-16 year in half-hourly intervals for the 14 DNO regions.

Analysis of the results show weekdays have the highest level of fluctuation in prices with distinctive peaks in the early evening, while weekend profiles are a bit more flat in nature. Also it is evident electricity from November to February is the most expensive period overall with very expensive peaks. The most drastic example is the WPD South Western England region which charges $73.56 \mathrm{p} / \mathrm{kWh}$ in a winter weekday evening. Nonetheless, expensive peaks do not correlate clearly with most expensive rates over the year. NPG Yorkshire was determined the most expensive region in the UK with a rate of $10.29 \mathrm{p} / \mathrm{kWh}$, however its evening peaks ranked $11^{\text {th }}$ place. Meanwhile the London area has the lowest rates in the country. Further research on network charges and analysis on the weight of each tariff component is required in order to identify more insights into the subtleties of commercial electricity bills.

It is important to stress that due to the nature and dynamics of the UK power market the methodology presented here needs to be frequently updated as it's subject to change to policy initiatives and market externalities. We expect the output from this work will allow decision makers to take a step forward into developing valuable costing models that can diffuse a broad range of economic research into energy systems within a commercial context.

\section{ACKNOWLEDGMENT}

The research was supported by funds provided via the Imperial College London-Sainsbury's Supermarkets LTD partnership.

\section{REFERENCES}

[1] Department of Energy \& Climate Change - DECC (2015, October 29). "International industrial energy prices" [Online]. Available: https://www.gov.uk/government/statistical-data-sets/internationalindustrial-energy-prices

[2] Utilyx (2013). "Coming of Age - Decentralised Energy?" [Online]. Available: http://www.utilyx.com/news/energy-insights/?fileid=22

[3] UK Energy Research Council - UKERC (2014, July 1). "UK Energy Strategies Under Uncertainty" [Online]. Available: www.ukerc.ac.uk/publications/uk-energy-strategies-underuncertainty.html

[4] Npower (2014, January 24) "RWE Npower Energy Explained: Inside the Cost of Energy (updated version)" [Online]. Available: http://www.npower.com/idc/groups/wcms_content/@wcms/@corp/doc uments/business/ee_latest_report.pdf

[5] The Carbon Trust (2013). "Energy Management Guide" [Online]. Available: http://www.carbontrust.com/resources/guides/energyefficiency/energy-management

[6] EDF Energy (2015) "Understanding Your Bill" [Online]. Available: http://www.edfenergy.com/large-business/customers/understandingyour-bill

[7] Elexon (2012). "Market Index Definition Statement for Market Index Data Provider(s) (Version 7.0)" [Online]. Available: https://www.elexon.co.uk/wp-content/uploads/2012/01/mids_v7.0.pdf
[8] OFGEM (2015, December 1) "DNO Charging Arrangements" [Online]. Available: http://www2.nationalgrid.com/UK/Industryinformation/System-charges/Electricity-transmission/Transmissionnetwork-use-of-system-charges/

[9] Elexon (2013, November 7) "Elexon Guidance: Transmission Losses" [Online]. Available: https://www.elexon.co.uk/wpcontent/uploads/2013/11/transmission_losses_v4.0_cgi.pdf

[10] National Grid (2015, December 1) "Balancing Services Use of System" [Online]. Available: http://www2.nationalgrid.com/bsuos/

[11] OFGEM (2015, April 1). "Renewables Obligation Certificates ROCs" [Online]. Available: https://www.ofgem.gov.uk/environmentalprogrammes/renewables-obligation-ro

[12] OFGEM (2015) "Feed-in Tariff: Tariff Tables" [Online]. Available: https://www.ofgem.gov.uk/environmental-programmes/feed-tariff-fitscheme/tariff-tables

[13] HM Revenues \& Customs - HMRC. (2015, April 6) "Guidence on Climate Change Levy Rates" [Online]. Available: https://www.gov.uk/government/publications/rates-and-allowancesclimate-change-levy/climate-change-levy-rates

[14] National Grid (2015, July 31) "Assistance for Areas with High Electricity Distribution Costs" [Online]. Available: http://www2.nationalgrid.com/UK/Industry-information/Systemcharges/Electricity-transmission/Assistance-for-areas-with-highdistribution-costs/

[15] Department of Energy \& Climate Change - DECC (2015, May 26) "Electricity Market Reform: Contracts for Difference" [Online]. Available: https://www.gov.uk/government/collections/electricitymarket-reform-contracts-for-difference

[16] Department of Energy \& Climate Change - DECC (2015, June 15) "Electricity Market Reform: Capacity Market" [Online]. Available: https://www.gov.uk/government/collections/electricity-market-reformcapacity-market

[17] Octego (2015, April 1) "Shifting the Balance: The Rise of Third Party Energy Charges" [Online]. Available: http://octego.com/wpcontent/uploads/2015/04/Octego-Quarterly-Review-April-15-Shiftingthe-Balance-v.3.pdf

[18] Energy Networks Association (ENA) (2014, April 1) "Electricity Distribution Map Info" [Online]. Available: http://www.energynetworks.org/info/faqs/electricity-distributionmap.html

[19] Northern Ireland Electricity Networks (2015, April 1) "Northern Ireland Electricity Networks Website" [Online]. Available: http://www.nienetworks.co.uk/

[20] UK Power Networks (2015, April 1) "UK Power Networks Website" [Online]. Available: http://www.ukpowernetworks.co.uk

[21] Western Power Distribution (2015, April 1) "Western Power Distribution Website" [Online]. Available: http://www.westernpower.co.uk

[22] Northern Powergrid (2015, April 1) "Northern Powergrid Website" [Online]. Available: http://www.northernpowergrid.com

[23] SP Energy Networks (2015, April 1) "SP Energy Networks Website" [Online]. Available: http://www.spenergynetworks.co.uk/

[24] Electricity North West (2015, April 1) "Electricity North West Networks Website" [Online]. Available: http://www.enwl.co.uk

[25] Scottish and Southern Energy (2015, April 1) "Scottish and Southern Energy Website" [Online]. Available: http://www.ssepd.co.uk

[26] National Grid (2015, March 27) "Triad Data" [Online]. Available: http://www2.nationalgrid.com/UK/Industry-information/Systemcharges/Electricity-transmission/Transmission-Network-Use-ofSystem-Charges/Transmission-Charges-Triad-Data/

[27] EDF (2015, December 1) "Flexible Electricity Contracts from EDF Energy" [Online]. Available: https://www.edfenergy.com/sites/default/files/flexible_electricity_contr acts.pdf 